\section{Global precarious employment and health inequalities: working conditions, social class, or precariat?}

Emprego precário no mundo e desigualdades em saúde: condições de trabalho, classe social ou precariado?

Empleo global precario e inequidades en salud: ¿condiciones laborales, clase social, o "precariado"?
Carles Muntaner 1,2

\author{
Correspondence \\ C. Muntaner \\ Social and Behavioral \\ Sciences Division, Dalla Lana \\ School of Public Health, \\ University of Toronto. \\ Suite 381, 3rd Floor Health \\ Sciences Building, 155 College \\ Street, Toronto, M5T 1 P8 \\ Canada. \\ carles.muntaner@utoronto.ca
}




\section{Introduction}

One of the recent social science findings in wealthy countries has been that the post-World War II boom characterized by unprecedented levels of economic wellbeing for working classes in Europe and North America 1,2 was in fact a historical exception in the evolution of capitalism 3 . Since the mid-1970s, the era of globalization, with increasing manufacturing and investment in low and middle-income countries (LMICs), the growing role of finance, declining real wages, lower union membership, and deregulation of labor markets have rolled back those standards for large proportions of working classes 4 . Changes in employment conditions during this period have been referred to as precarious employment 5 , and terms such as flexible, atypical, temporary, part-time, contract, self-employed, irregular, or non-standard employment have also been used $6,7,8$. The most distinctive property of precarious employment is uncertainty in the duration of the labor contract, although other features such as psychological job insecurity, employment strain (i.e., the effort in continuously searching for jobs), low wages and lack of benefits, hazardous physical and psychosocial working conditions, and de facto or real absence of legal protection have been included among its indicators 9,10. Although the field of health inequalities began to take off in the early 1990s 11, it was not until the 21st century that public health researchers began to investigate the health effects of precarious employment 12,13,14.

Despite the growth of research on precarious employment in social 15 and public health sciences 16 , skeptics question the construct's usefulness. Critiques fall into two main areas: historical (novelty and regional scope of the construct) and sociological (in particular theoretical and social class-related). In this essay I review some of the current critiques of the precarious employment construct and advance some potential solutions for its use in epidemiology and public health.

\section{Does precarious employment represent a new set of employment conditions?}

From a historical perspective, precariousness is hardly a novelty in either wealthy countries or LMICs. For example, the terminology has changed, but what we call now precarious employment may not be so different from Asa Cristina Laurel's "subproletariado urbano" 16. LMICs did not experience a post-World War II "Golden Age" of capital-labor relations 17 and, even today the largest segment of their labor markets often consists of workers who lack the social security benefits and legal and social protection associated with the post-World War II standard employment relationship in wealthy countries 18 . Just as economic inequality in capitalism has been the norm rather than the exception 3 , so have precarious employment conditions. Marx, in volume 1 of Das Kapital, described the employment conditions of workers as precarious 19 . One could claim that precarious employment was the norm in the United States until the 1930s 15. This situation has led some social scientists to reject the construct of precarious employment altogether 20,21, which might be premature; empirically, indicators of precarious employment are able to predict health inequalities in contemporary labor markets with magnitudes comparable to common socioeconomic indicators, and its theory is integrated with macro and micro models in social epidemiology 8 . The solution is to approach precarious employment as a historical construct 4 with its own political, economic, and cultural specificity. For example, precarious employment represents a decline in working class employment standards from the historically post-World War II "high point" 15.

\section{Can we generalize precarious employment across the globe?}

Another level of complexity in any attempt to generalize the precariousness construct and its measurement is the large proportion of informal workers in LMICs. Informal work is analyzed separately from the precariousness of workers in wealthy countries' labor markets 9 , because it typically lacks legal labor contracts which create an additional set of social and health problems 22,23 . Thus, even if we define precarious employment with a set of core properties, for example, jobs that are uncertain, unpredictable and risky from the worker's point of view 15 , the precariousness construct will probably require fine tuning in different regions. In other words, what is considered precarious in Norway may not be seen as precarious in Colombia.

Labor market regulation and social protection such as universal healthcare, size of the informal workforce, and other factors might require specific indicators of precarious employment in different labor markets. As in other constructs in the history of social epidemiology, e.g. type A behavior, job demands, and social capital, attention to historical and regional heterogeneity is critical to both the instruments' validity and the construct's heuristics 24 . 


\section{Precarious employment or precarious workers?}

Because precarious employment remains a contested concept, it is still unclear whether it refers to a social relationship, i.e., the employment relationship between buyers and sellers of labor, or to an individual attribute 25 . Making precariousness a psychological rather than a sociological construct has consequences for both explanation and policy. Psychological precariousness would lead to modifying the behavior of "vulnerable" workers so they can adjust to the labor market, while a focus on the precarious employment relationship would lead to changes in labor market policy (e.g., unemployment compensation, active labor market policies, living wage, or "flexicurity" labor markets) 26 .

When the precarious employment relationship is reduced to a property of the person (e.g., weight or height, as in "vulnerable" or "precarious" workers), the employment relationship remains theoretically and empirically invisible, ensuring that no labor market policy can emerge from findings that would challenge current labor market conditions 27 . Common measures of precarious employment suffer from this theoretical limitation. When using a single indicator of subjective precariousness (e.g., job insecurity) or a scale in which the employment relationship is combined with psychosocial indicators, it is easy to reify precarious employment as a personal attribute 28 . Such reification has the additional danger of creating an artificially separate group of "vulnerable" workers, minimizing the employment concerns raised by the remaining workforce.

\section{Is precarious employment a social class relationship?}

Several scholars contend that precarious employment is merely a feature of working class employment and that there is no further need for such a construct 19,20. From this perspective, employment insecurity and exploitation are characteristics of all workers under capitalist production, and what we call precariousness refers to a higher level of exploitation 29. Precarious conditions such as job and employment insecurity, employment strain, low wages, and lack of workers' control over the work process characterize working class positions (persons who are employed by someone else and are not in management positions) ${ }^{30}$. Yet precarious employment refers to contemporary working conditions with high levels of domination, exploita- tion, and poor health among working class positions 22,31. Precarious employment and social class are thus complementary, both theoretically and empirically.

Subsuming precarious employment conditions under social class mechanisms (employment relations based on worker domination and exploitation) 29,32 provides an explanation for its origins and continuation. Rooting precarious employment in social class also avoids the confusion between precarious employment and other social relations involving gender, age, credentials, or migrant status ${ }^{4}$. The social mechanism underlying precarious employment, e.g., employment insecurity, lack of benefits, low wages, vulnerability to employment abuse, is the employment relationship (i.e., social class), not the fact that a particular worker might be of a certain gender, race, ethnic group, religion, nationality, or age. Considering these forms of social relations in analyses of precarious employment is nonetheless crucial, since precariousness is more frequent among workers that suffer discrimination according to gender, race, ethnicity, age, or nationality 8 .

Precariousness has also been defined in terms of class politics in Guy Standing's The Precariat: The New Dangerous Class 4 , whereby workers in precarious employment positions act politically according to their class interests. Whether workers in precarious employment positions are able to organize and become major political class actors 4 depends on social context. Precariousness is highly ubiquitous, and its study is not sufficiently developed to warrant generalizations. Examples point to both the difficulty of organizing 33 and to successes of working with labor unions 34 .

\section{Precarious employment is here to stay}

Given the evolution of labor markets in wealthy countries and LMICs, the set of employment conditions known as precarious employment is bound to continue for the foreseeable future 35 . One example is the outcome of the European recession. Rather than relying on Keynesian or Social-Democratic policies, the way out of the great recession seems to be the further precarization of the working classes. For example, the recent growth of the Spanish economy has been fueled by a labor market reform that all but neutralizes collective bargaining and new work contracts (80\% of which are precarious) ${ }^{36}$. Within this context, social epidemiologists are well-positioned to document and explain the relationship between precarious employment and health 8 so that the 
link to policy solutions is explicit 37 . Public health practitioners, in particular those in occupational health, can engage stakeholders and inter-sector policies to eliminate precarious employment, including legislation, labor market regulation, and enforcement 18,34,38.

\section{References}

1. Esping-Andersen G. The three worlds of welfare capitalism. Princeton: Princeton University Press; 1990.

2. Korpi W. Economic growth and the welfare state: leaky bucket or irrigation system? Eur Sociol Rev 1985; 1:97-118.

3. Piketty T. Capital in the twenty-first century. Cambridge: Belknap Press; 2014.

4. Standing G. The precariat: the new dangerous class. London: Bloomsbury Academic; 2011.

5. Bourdieu P. Practical reason: on the theory of action. Stanford: Stanford University Press; 1998.

6. Standing G. Global labour flexibility: seeking distributive justice. London: Palgrave Macmillan; 1999.

7. Benach J, Muntaner C. Precarious employment and health: developing a research agenda. J Epidemiol Community Health 2007; 61:276-77.

8. Benach J, Vives A, Amable M, Vanroelen C, Tarafa G, Muntaner C. Precarious employment: understanding an emerging social determinant of health. Annu Rev Public Health 2014; 35:229-53.

9. Lewchuk W, Marlea C. Working without commitments: the health effects of precarious employment. Montreal: McGill-Queen's University Press; 2011.

10. Vives Vergara A. A multidimensional approach to precarious employment: measurement, association with poor mental health and prevalence in the Spanish workforce [Doctoral Dissertation]. Barcelona: Universitat Pompeu Fabra; 2010.

11. Bouchard L, Albertini M, Batista R, de Montigny J. Research on health inequalities: a bibliometric analysis (1966-2014). Soc Sci Med 2015; 141:100-8.

12. Muntaner C, Barnett E. Depressive symptoms in rural West Virginia: labor market and health services correlates. J Health Care Poor Underserved 2000; 11:284-300.

13. Benach J, Benavides FG, Platt S, Diez-Roux A, Muntaner C. The health-damaging potential of new types of flexible employment: a challenge for public health researchers. Am J Public Health 2000; 90:1316-7.

14. Benavides FG, Benach J, Diez-Roux AV, Roman C. How do types of employment relate to health indicators? Findings from the second European survey on working conditions. J Epidemiol Community Health 2000; 54:494-501.
15. Kalleberg AL. Precarious work, insecure workers employment relations in transition. Am Sociol Rev 2009; 74:1-22.

16. Laurell AC, Serrano M. Crisis y salud en América Latina. Cuadernos Políticos 1982; 33:32-45.

17. Marglin SA, Schor J, editors. The golden age of capitalism. Oxford: Clarendon Press; 1990.

18. Casale G, editor. The employment relationship: a comparative overview. Oxford: Hart Publishing; 2011.

19. Magdoff F, Foster JB. The plight of the US working class. Mon Rev 2014; 65:1-22.

20. Breman J. A bogus concept. New Left Rev 2013; 84:130-8.

21. Doogan K. New capitalism? The transformation of work. Cambridge: Wiley; 2009.

22. Rocha KB, Muntaner C, Solar O, Borrell C, Bernales P, González MJ, et al. Clase social, factores de riesgo psicosocial en el trabajo y su asociación con la salud autopercibida y mental en Chile. Cad Saúde Pública 2014; 30:2219-34.

23. de Andrade LOM, Pellegrini FA, Solar O, Rígoli F, de Salazar LM, Serrate PC, et al. Determinantes sociales de salud, cobertura universal de salud y desarrollo sostenible: estudios de caso en países latinoamericanos. MEDICC Review 2015; 17 Suppl:S53-61.

24. Muntaner C, Eaton WW, Miech R, O’Campo P. Socioeconomic position and major mental disorders. Epidemiol Rev 2004; 26:53-62.

25. Anderson B. Migration, immigration controls and the fashioning of precarious workers. Work Employ Soc 2010; 24:300-17.

26. Lee S, McCann D. Regulating for decent work: new directions in labour market regulation. New York: Palgrave Macmillan; 2011.

27. Muntaner C. Invited commentary: on the future of social epidemiology - a case for scientific realism. Am J Epidemiol 2013; 178:852-7.

28. Gould SJ. The mismeasure of man. New York: Norton \& Company; 1981.

29. Muntaner C, Ng E, Chung H, Prins SJ. Two decades of Neo-Marxist class analysis and health inequalities: a critical reconstruction. Soc Theory Health 2015; 13:267-87. 
30. Puig-Barrachina V, Vanroelen C, Martínez J, Vives A, De Moortel D, Benach J. How does precarious employment relate to health and job satisfaction in Europe? A gender and cross-national perspective. Eur J Public Health 2014; 24:cku166.085.

31. Rocha KB, Muntaner C, González Rodríguez MJ, Baksai PB, Vallebuona C, Borrell C, et al. Social class, health inequalities, and health-related behaviors of working people in Chile. Rev Panam Salud Pública 2013; 33:340-8.

32. Muntaner C, Borrell C, Vanroelen C, Chung H, Benach J, Kim IH, et al. Employment relations, social class and health: a review and analysis of conceptual and measurement alternatives. Soc Sci Med 2010; 71:2130-40.

33. Bilbao A. El empleo precario. Seguridad de la economía e inseguridad en el trabajo. Madrid: Los Libros de la Catarata; 1999.

\section{Resumo}

Mudanças nas condições de emprego desde os anos 1980 s têm sido chamadas de "emprego precário", além de outros termos como trabalho flexível, atípico, temporário, em tempo parcial, por contrato, autônomo ou irregular. O ensaio faz uma revisão de algumas das críticas atuais em relação ao conceito de emprego precário e propõe soluções para seu uso na epidemiologia e em saúde pública.

Saúde do Trabalhador; Condiç̃es de Trabalho; Classe Social
34. Vosko LF. Precarious employment: understanding labour market insecurity in Canada. Quebec: McGill-Queen's University Press; 2006.

35. Therborn G. The killing fields of inequality. Malden: Polity Press; 2014.

36. Black WK. Spain rains on the austerity victory parade. Challenge 2014; 57:42-53.

37. O' Campo P, Dunn JR. Rethinking social epidemiology: towards a science of change. New York: Springer; 2011.

38. Heymann J, Earle A. Raising the global floor: dismantling the myth that we can't afford good working conditions for everyone. Stanford: Stanford University Press; 2010.

\section{Resumen}

Tras los cambios en las condiciones laborales desde los años 1980s se ha hecho uso de conceptos como empleo precario, así como de términos como: flexible, atípico, temporal, a tiempo parcial, contrato basura, autoempleado, irregular, o empleo no convencional. En este trabajo se realizó una revisión sobre algunas de las actuales críticas hacia el constructo del empleo precario y se avanzaron algunas soluciones potenciales para su uso en epidemiología y salud pública.

Salud Laboral; Condiciones de Trabajo; Clase Social 